\title{
Assessment of Different Factors for Buffalo Rearing and their Housing Management in Different Villages of Chaka Block of Allahabad
}

\author{
Ashish Awasthi ${ }^{1}$ and Sumira Malik ${ }^{2 *}$ \\ ${ }^{1}$ Department of animal husbandry and dairying, SHUATS, Allahabad, India \\ ${ }^{2}$ Department of Agriculture \& Forestry, Shivalik college of Engineering, Dehradun, India \\ *Corresponding author
}

Keywords

Age, Gender, Education, Buffalo rearing, Chaka block, Income generation

Article Info

Accepted:

07 December 2018

Available Online:

10 January 2019

\section{A B S T R A C T}

A semi structured questionnaire based field survey was conducted to assess the socioeconomic factors, responsible for the buffalo rearing in the 11 villages of Chaka block of Allahabad. The recent study was performed on the respondents of different age group, gender, education status, factors and other characteristics that include breeds, rearing and housing strategies of the various buffalo in these different villages of Chaka region. The current data concluded, requirement of enhanced literacy rate, social awareness, market perception for attaining the knowledge of demand of product in market and huge involvement of active and educated youth of early twenties with poorly educated elder farmers of their families. With the improvement in these factors, they cannot only learn to select the efficient breed of buffalo but also practice scientific rearing methods and work upon management practices, according to their requirement and environmental conditions. Eventually, these farmers involved in buffalo rearing can also focus on different and latest strategies of dairy farming for the production of higher yield of milk, processed milk products and meat as source of extra income generation for better livelihood and employment.

\section{Introduction}

In livestock, buffalo is considered as an integral component of Indian agricultural economy and it has significant role in livelihood and food security. In developing country like India with 108.7 million populations of buffalo contribute $51.06 \%$ (74.71 million tons) to the total milk production in the country and there are only 13 registered breeds and it ranks $1^{\text {st }}$ in world (Jakhar et al., 2017). It is considered as one of the enduring species from ungulates and sustainable to all odds of climatic and epidemic condition. Their survival rate is very high and survives on poor quality inputs which make them prior and sustainable choice for millions of poor farmers.

They are cost effective with low labor requirement and most versatile among all work animals. Buffaloes are also used as draught animal. Out of total breed able buffaloes in India, only $15-20 \%$ is bred 
through artificial insemination whereas rests of $80-85 \%$ are covered by natural services through scrub bulls.

The milk of buffalo has higher fat, protein, mineral contents and about half of the cholesterol content than that of cow's milk. Milk of buffalo is also comprised of high quality proteins with all the essential amino acids in the appropriate proportions according the requirement of an individual's body. It is preferred by the consumer as it is rich in nutrition and also can be easily transformed into beneficial commercial products such as yogurt, ice cream and cheese. Comparative to cow's milk it has higher content of fat, casein, whey proteins (Khedkar et al., 2016). Buffalo, contribute $19 \%$ of total meat production in India (BAHS, 2014). These buffaloes are triple purpose animal which provides milk, meat and milk products and acts as the primary sources of livelihood substance for millions of small holders farmers in India contributing in the economy of several others countries. Indian buffaloes are one of the major sources of milk supply with thrice yield comparative to cows. According to previous studies, 47.22 million milch buffaloes contribute from the $55 \%$ of total production of milk in India (Yadav et al., 2017). There are about 13 indigenous standard breeds of buffaloes, which are well known for their milking qualities. Globally, the population of buffalo has reached to 130 million, they are considered as an important variety but as an undervalued asset (FAO 2000). In developing country like India it is considered as premier animal of an dairy industry and it has contribution of $50 \%$ of total milk production (FAOSTAT 2005). From the Asian domesticated animals, Asian buffalo is known for its promising potential for production (Cockrill et al., 1994).

These are preferred over cattle in India because of their distinctive qualities such as better feed conversion efficiency, more resistance to diseases and higher milk fat percentage than in cows (Bandyopadhyay et al., 2003). Agriculture continues to be the primary industry in India which directly or indirectly supports more than 50 percent of the Indian population. However, agriculture in India has always been heavily dependent on the fluctuation in weather conditions. Indirectly, climatic fluctuations impact through rainfall variability, availability of irrigation, intensity seasonal droughts and floods, soil erosion, change in pest profiles, with tremendous impact on agricultural production and simultaneously food production (Aggarwal et al., 2003). In such case diversification by increasing the share of income from allied sectors becomes important. Besides directly benefiting the rural economy, the buffalo meat industry also provides raw material for allied sectors. Driven by the structural changes in agriculture and food consumption patterns, the importance of buffalo meat sector has been undergoing a steady transformation. The expanding domestic market as well as export markets for buffalo meat is creating a window of opportunity for all the actors in the value chain of buffalo meat production. Buffalo contributes about $30 \%$ of the total meat production in the country. The buffalo meat sector therefore is one of the important sectors in Indian economy. However, with changing world food production and consumption patterns, there is a need to develop a strategy for the future by analyzing different segments of the value chain of buffalo meat production. The buffalo holds an important place and role in Indian rural economy.

Buffalo rearing is one of the most important occupations of rural society and constitutes the livelihood of rural poor belonging to the lowest socioeconomic strata. The rural people lack knowledge, literacy, social awareness which arise the requirement of improvement 
in knowledge about buffalo's foundation stock, their proper housing, feeding and management. Livestock is an important component of India's economy in terms of income, employment and foreign exchange earnings. The distribution of livestock is more justifiable and its growth is considered to be a major contributor as an anti-poverty and e quity-oriented (Adams and $\mathrm{He}$ 1995; Birthal and Singh 1995). If poor and rural farmers could be trained to attain the scientific buffalo rearing protocols and methods, than these farmers cannot only generate it as a source of income but also as an employment. They can also generate income from other sources as from livestock sector buffalo meat can also serve as a source of income. Therefore, the present study highlights the factors such as literacy, gender and age factor which may directly or indirectly contribute in the development of awareness among farmers on scientific buffalo rearing and vice versa in gainful income generation. This study also invites the requirement of further research on the constraints faced by farmers, management practices and disease prevention of buffalo and in the various villages of Chaka block of Allahabad.

\section{Materials and Methods}

\section{Description of the Allahabad district}

The Allahabad district has 557 Milk societies, 153 veterinary hospitals and 98 pashu sewa Kendra, Allahabad is situated in the alluvial plain of eastern part of Uttar Pradesh. The area of the Allahabad district is $5482.10 \mathrm{sq} . \mathrm{km}$ and it is bordered by Pratapgarh and Jaunpur in north, Varanasi in east and Mirzapur is the south.

Allahabad is located at $25.45^{\circ} \mathrm{N}, 81.84^{\circ} \mathrm{E}$ in the southern part of Uttar Pradesh at an elevation 98 meters (322 ft.) and stands at the confluence of two rivers Ganges and Yamuna.
The population of the district is 49.36 lakhs with population density 911 persons per sq $\mathrm{km}$. There are 8 Tehshils and 20 Blocks, 218 Nyaypanchayat and 218 Gram Sabha. The district is rich in animal resources particularly dairying

\section{Sampling procedure from study area}

The present study was conducted in Chaka block of Allahabad district, Uttar Pradesh. Study area includes 11 randomly selected villages of Chaka block and 100 randomly selected buffalo owners of selected villages for personal interview. Collection of data was done with the help of well-structured questionnaire in each of the study location. Buffalo farmers were randomly selected through stratified sampling procedure and individually interviewed. Buffalo farmers from different villages were interviewed using well structure questionnaire which covered information regarding gender, age, education of the respondents including herd size, types of breeds of buffalo, herd distribution and the housing pattern of buffalo rearing.

\section{Data collection from study area}

Data collection was done during the months of February to May 2017 and well-structured questionnaires were used to collect relevant information's from the farmer through personal interview. Information on buffalo herd size, types of breeds, their herd distribution and housing pattern of rearing has been collected from small and marginal farmer data were collected with other factors such as farmer respondent's age, gender, and educational level.

\section{Results and Discussion}

\section{Demographic information}

Information on distribution of buffaloes in 11 randomly selected villages of Chaka block of 
Allahabad district of Uttar Pradesh, were collected through structured questionnaires from randomly selected 100 buffalo farmers in the study area as shown below in Table 1 .

Gender wise determination of number of respondents in dairy farming and buffalo rearing-

The study revealed that among total buffalo farmers of the selected 11 villages, $83 \%$ were the male respondents and $17 \%$ were the female respondents. The result has been calculated for gender and its percentage as shown in the Figure 1.

Determination of Age of respondents involved dairy farming and buffalo rearing

The study revealed that $18 \%$ of the respondents were between the age group of 21- 30 years, $53 \%$ of respondents were between the age group of 31-40 years where as remaining $29 \%$ of respondents were between the age group of 41-50 years as shown in Figure 2.

Study of educational status of the respondents

The study indicates that about $25 \%$ of the respondents had completed their primary education, $15 \%$ completed secondary education, $20 \%$ had completed higher secondary education and $40 \%$ of the respondents were found illiterate as explained in Figure 3.

\section{Evaluation of breeds of buffalo reared by} respondents

The results from Figure 4 revealed that 25\% buffalo farmers of the selected area had Murrah breed, $50 \%$ of farmers had nondescript breeds, where as $25 \%$ of the respondents had cross bred buffalo.
Evaluation of herd distribution pattern by villagers of chaka block

The herd distribution pattern of the study area revealed that out of total buffalo herd of Chaka block, Milch buffaloes constitute $42.94 \%$, female calves constitute $34.96 \%$ and $22.08 \%$ male calves constitute to the total herd. The result is explained in Figure 5.

\section{Study of Buffalo rearing system in selected area of Chaka region}

Most of the respondents about $43 \%$ reared their buffalo under Intensive system; while $30 \%$ respondents reared under free scavenging system and remaining $27 \%$ of the respondents kept their buffaloes under semi intensive system. The results are represented in Figure 6.

Evaluation of Herd size of buffalo by various owners of villages of Chaka block

Most of buffalo farmers about $15 \%$ had herd size less than 5 buffalo, $35 \%$ of the farmers had herd size between $5-10$ buffaloes, $40 \%$ of the farmers had herd size between 10-20 buffalo,and $10 \%$ of the farmers had herd size between $20-50$ or above buffaloes. The result are shown in Figure 7.

\section{Study of housing management facilities for buffalo in chaka region of Allahabad}

It was observed that $70 \%$ of the respondents maintain their buffaloes under open system of housing and $30 \%$ of the respondents maintained buffaloes under in close system of housing. A total of $34 \%$ of the respondents had Pucca type of housing and 66\% of the respondents had Kuchcha type of housing. About $47 \%$ of the buffalo farmers had buffalo shed/house attached to human dwelling and $53 \%$ of the farmer had buffalo shed/house nearby their dwelling (Table 2). 
Table.1 Number and percentage of respondents in selected villages of Chaka block of Allahabad

\begin{tabular}{|c|c|c|c|}
\hline $\begin{array}{c}\text { S. } \\
\text { No. }\end{array}$ & Villages & No. of respondents & $\begin{array}{c}\text { \% of respondents } \\
\text { re respondents }\end{array}$ \\
\hline 1. & Nibi & 11 & 11 \\
\hline 2. & Tinuvaban & 9 & 9 \\
\hline 3. & Sanjay nagar & 7 & 7 \\
\hline 4. & Chakabhayram & 8 & 8 \\
\hline 5. & Chaka & 12 & 12 \\
\hline 6. & Chauktha & 6 & 6 \\
\hline 7. & Chakgarib das & 7 & 7 \\
\hline 8. & Chakdubrajpur & 9 & 9 \\
\hline 9. & Ghoghapur & 10 & 10 \\
\hline 10. & Devari & 11 & 11 \\
\hline 11. & Dabhaon & 10 & 10 \\
\hline & Total & $\mathbf{1 0 0}$ & $\mathbf{1 0 0}$ \\
\hline
\end{tabular}

Table. 2 Housing management strategies adopted by buffalo farmers in selected villages of chaka region

\begin{tabular}{|c|c|c|c|c|}
\hline S. No. & Particular & Type of housing & No. of respondents & $\%$ of type of housing \\
\hline \multirow[t]{4}{*}{1.} & \multirow[t]{4}{*}{ Type of housing } & Open & 70 & 70 \\
\hline & & Close & 30 & 30 \\
\hline & & Pucca & 34 & 34 \\
\hline & & Kuchcha & 66 & 66 \\
\hline \multirow[t]{2}{*}{2.} & \multirow[t]{2}{*}{$\begin{array}{l}\text { Location of } \\
\text { shed/house }\end{array}$} & $\begin{array}{l}\text { Attached to human } \\
\text { dwelling }\end{array}$ & 47 & 47 \\
\hline & & Nearby their & 53 & 53 \\
\hline \multirow[t]{2}{*}{3.} & \multirow[t]{2}{*}{ Type of floor } & Kuchcha & 75 & 75 \\
\hline & & Pucca & 25 & 25 \\
\hline \multirow[t]{4}{*}{4.} & \multirow[t]{4}{*}{ Type of roof } & No roof & 25 & 25 \\
\hline & & $\begin{array}{c}\text { Asbestos sheets } \\
\text { ranf }\end{array}$ & 30 & 30 \\
\hline & & $\begin{array}{l}\text { Galvanized iron } \\
\text { sheets roof }\end{array}$ & 25 & 25 \\
\hline & & Thatched roof & 20 & 20 \\
\hline \multirow[t]{2}{*}{5.} & \multirow[t]{2}{*}{ Cleanliness of floor } & Dirty & 58 & 58 \\
\hline & & Clean & 42 & 42 \\
\hline
\end{tabular}


Fig.1\&2 Graphical representation of Gender based number and percentage of respondents \& Graphical representation of age wise per cent of respondents
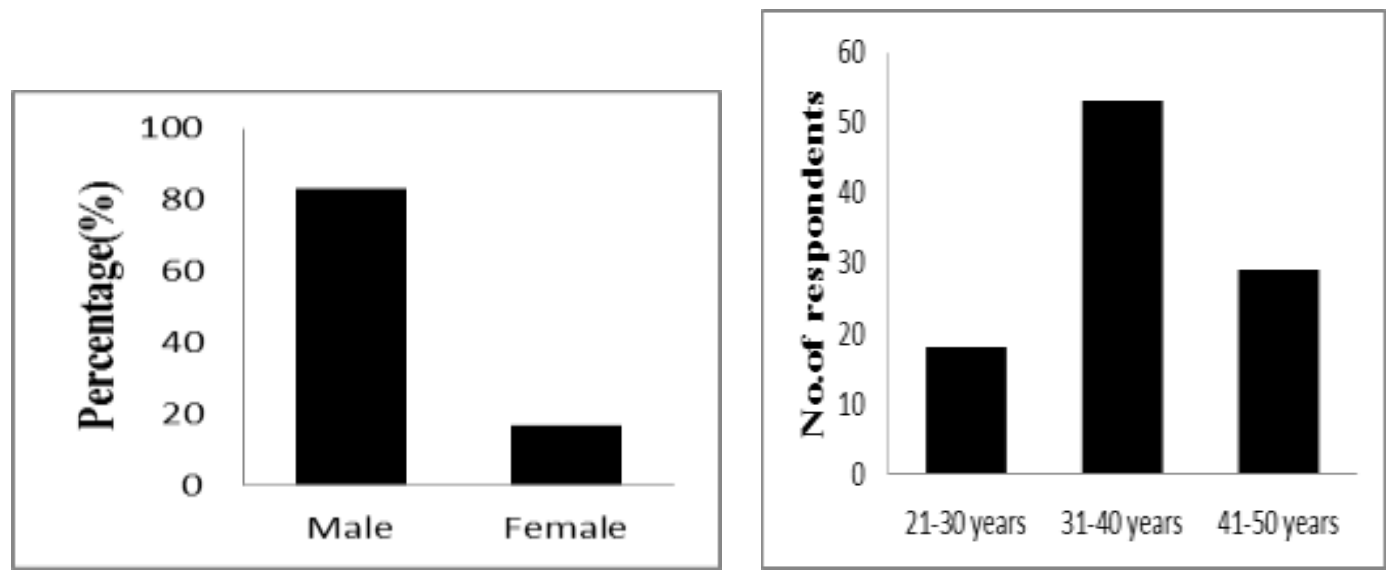

Fig.3\&4 Graphical presentation of the percentage of respondents in educational category \& Breed wise number and per cent of buffaloes reared by respondents in selected area
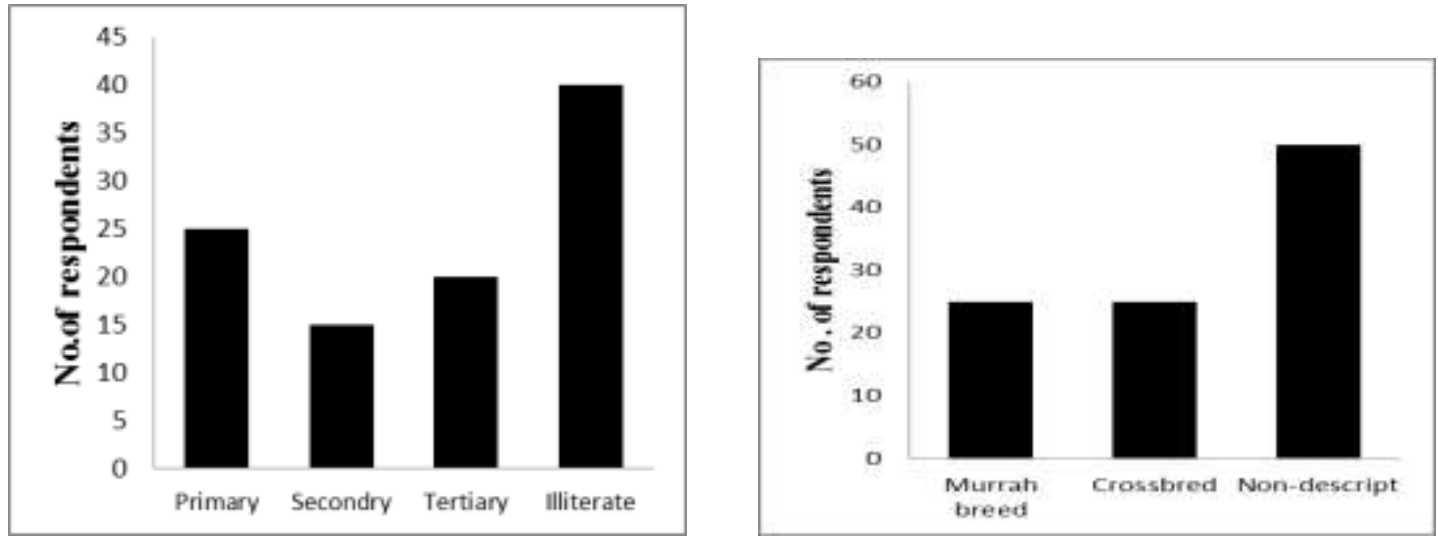

Fig.5\&6 Number and per cent of Animals in herd distribution \& Number and per cent of different type of Buffalo rearing system in selected area
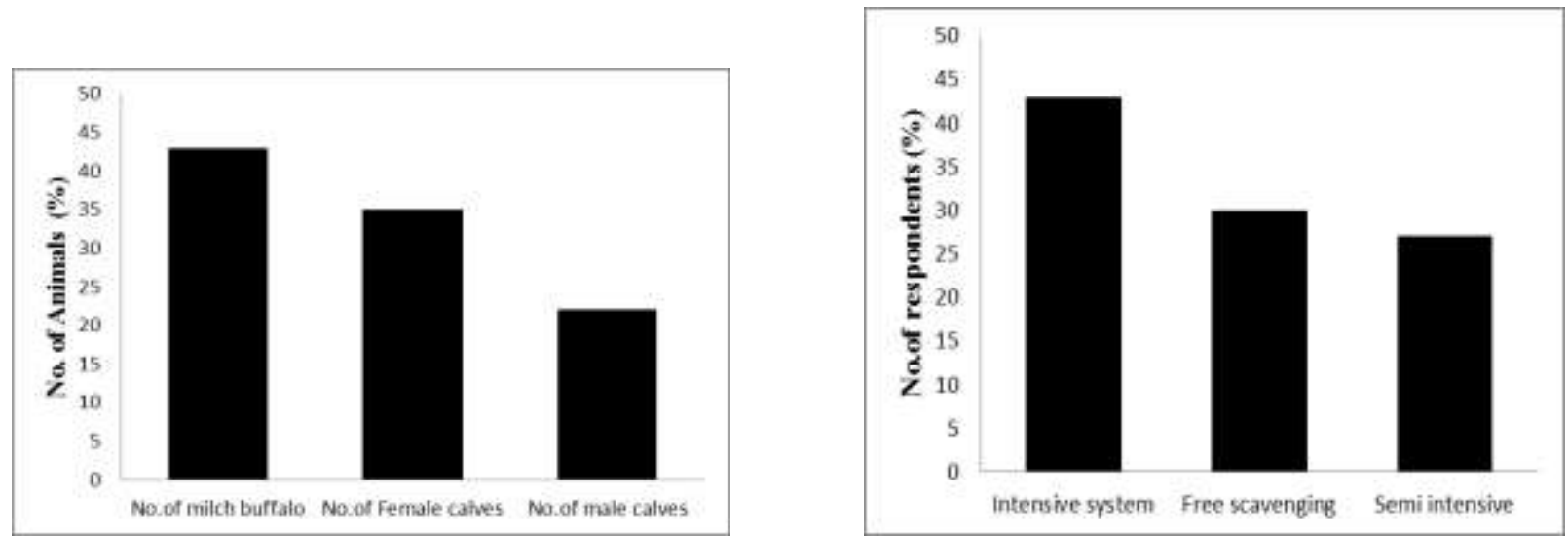
Fig.7 Number and per cent of different type of herd size kept by buffalo owners in selected villages of Chaka block

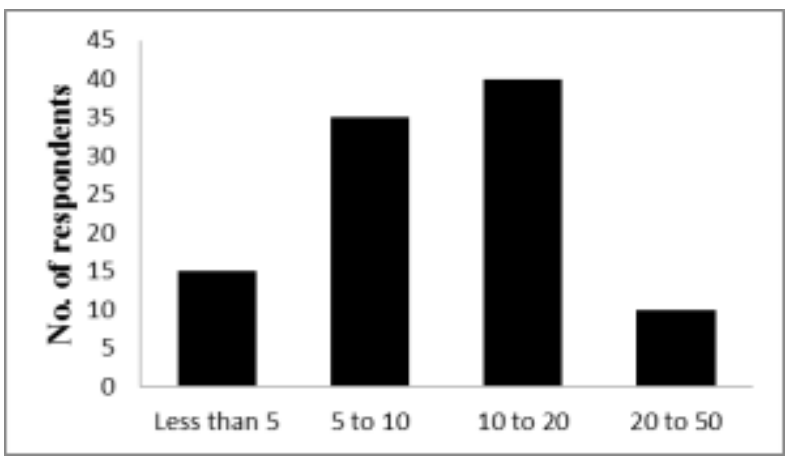

The study revealed that $75 \%$ of the respondents had the buffalo shed/house with Kachcha type of floor while $25 \%$ floors were Pucca type. Most of the farmers provided Kuchcha type of floor to lower the cost of construction.

Out of total of 100 respondents were randomly selected from 11 villages of Chaka block of Allahabad district were studied. In different regions $83 \%$ respondents were active male farmers and rest $17 \%$ females which suggest that involvement of females may help in increasing income generation through leaning of different processing for milk products. The $53 \%$ majority of the respondents were not involved in getting any education and belongs to age group of 31-40 years taking dairy farming as a sole source of business. Thus, it is suggested if physically and educationally active youngsters in twenties could support their village inhabiting elders to learn various methodologies of scientific dairy farming and cattle rearing under government based schemes. These government based schemes and programs through new techniques may support these village based uneducated and poorly educated farmers for the selection of cattle breeds, their rearing and breeding may aid in getting better of milk yield. The educational status of the respondents revealed that $40 \%$ of them were illiterate, $25 \%$ of the respondents were primary educated, $15 \%$ of them had secondary school educated and $20 \%$ of the respondents were undergone for higher secondary school education. However, 40\% respondents were uneducated and it highlights the requirement of education so they can enhance their awareness about high yielding milk breeds of buffalo for better yield of milk, earning through processing of milk products such as ghee, butter, cottage cheese, meat production and market demands. The $25 \%$ breeds of buffalo reared were crossbreds, $50 \%$ local breeds or non-descript and $25 \%$ were only of Murrah breed. This data suggests that because of low earning and poor education status their knowledge about high yielding milch breeds and their maintenance is one of the factors for lower income generation of farmers in these villages. Most of buffalo farmers, $15 \%$ farmers had herd size less than 5 buffalo, $35 \%$ of the farmers had herd size between 5-10 buffalo, $40 \%$ of the farmers had herd size between 10-20 buffalo and $10 \%$ of the farmers had herd size between 20-50 or above buffaloes. Very few farmers have satisfactory herd size of buffalo due to lack of adequate capital facilities for buffalo rearing. Herd distribution studies revealed that out of total buffalo reared $42.94 \%$ were female buffalo, $34.96 \%$ were buffalo female calf and $22.08 \%$ buffalo male calf, suggesting their interest only in milk production rather than milk products processing techniques from the 
rearing of approximately $75 \%$ female buffalo and calf. Most of the respondents $43 \%$ reared their buffalo under Intensive system while $30 \%$ of the respondents reared under free scavenging system and remaining $27 \%$ of the respondents kept their buffalo under semi intensive system. For the purpose of house management, $66 \%$ of the respondents had close housing system with kuchcha floor rather than pucca floor. This study concludes that there is requirement of basic and scientific education to introduce scientific strategies for cattle breeding, improved vision for breed selection to get better yield, involvement of capital for proper housing and management practices for rearing of buffalo rearing and to create awareness among the farmer for scientific selection of high milk yielding breeds, their rearing through organic feeding, methodologies to increase milk production yield and milk product processing along with marketing and finally elimination of the middlemen from the marketing channel to achieve maximum benefit.

\section{References}

Adams Jr., R.H. and He, J.J. 1995. Sources of income inequality and poverty in rural Pakistan. International Food Policy Research Institute, Washington, D.C.

Aggarwal, P. K.: 2003, 'Impact of climate change on Indian agriculture', J. Plant Biology 30(2), 189-198.

Bandyopadhyay A K, Ray R R and Ghatak P K. 2003. In proc: Effective utilization of buffalo milk for manufacturing dairy products. 4 th Asian buffalo congress, held at New Delhi from 2528 Feb: 191.

Birthal, P.S. and Singh, M.K. 1995. Structure of rural income inequality: a study in western Uttar Pradesh. Indian Journal of Agricultural Economics 50(2):168175

Cockrill W R 1994 Present and future of buffalo production in the world. Proceedings of the Fifth World Buffalo Congress, 27-30 June, Sao Paulo, Brazil.

FAO 2000 Water Buffalo: an Asset Undervalued, pp.1-6. FAO Regional Office for Asia and the Pacific, Bangkok, Thailand. http://www.aphca. org/publications/files/w_buffalo.pdf

FAOSTAT 2005 FAOSTAT Agriculture Data. Food and Agriculture Organization Statistics, Rome, Italy. http://faostat.fao.org/default.aspx

Jakhar, V., Vinayak, A.K. and Singh, K.P. (2017). Effect of Non-genetic Factors on Performance Traits of Murrah Buffaloes: Review Int.J.Curr. Microbiol.App.Sci. 6 (11): 4248-4255.

Khedkar C.D., Kalyankar S.D. and Deosarkar S.S. (2016) Buffalo Milk. In: Caballero, B., Finglas, P., and Toldrá, F. (eds.) The Encyclopedia of Food and Health vol. 1, pp. 522-528.

Yadav, A.K., Singh, J. and Yadav, S.K., Characteristic features of registered Indigenous Buffalo Breeds of India: A Review, Int. J. Pure App. Biosci. 5(4): 825-831 (20

\section{How to cite this article:}

Ashish Awasthi and Sumira Malik. 2019. Assessment of Different Factors for Buffalo Rearing and their Housing Management in Different Villages of Chaka Block of Allahabad. Int.J.Curr.Microbiol.App.Sci. 8(01): 904-911. doi: https://doi.org/10.20546/ijcmas.2019.801.098 